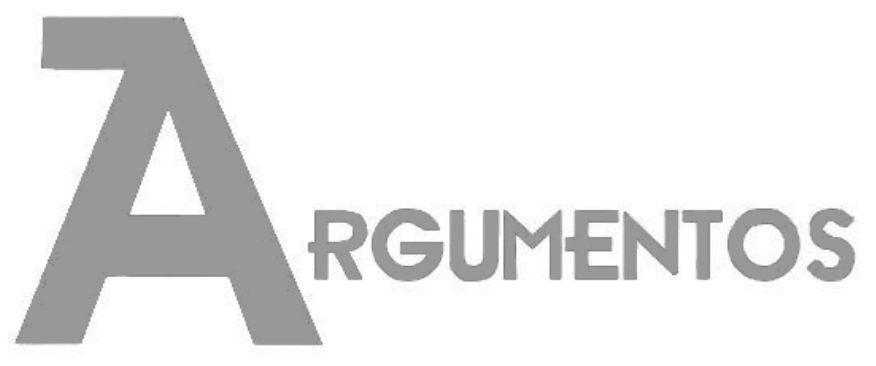

Vol. 17, n. 1, jan./jun. 2020 ISSN: 2527-2551 (online)

https://www.periodicos.unimontes.br/index.php/argumentos

\title{
Vestígios de um quilombo paulistano: uma análise da paisagem arqueológica do bairro do Bixiga
}

Alessandro Luís Lopes de Lima ${ }^{1}$

Recebido em: 09/12/2019

Aprovado em: 22/12/2019

\begin{abstract}
Resumo: Perante a destruição material das cidades, com o desmonte constante do patrimônio arqueológicos e arquitetônico, as ruas antigas permanecem protegidas pela necessidade cotidiana do uso público enquanto passagem. Buscamos na paisagem do bairro do Bixiga, as marcas da antiga população quilombola que ocupou as margens do córrego Saracura entre os séculos XVIII e XIX. Através da análise da cartografia-histórica da cidade de São Paulo, procuramos resgatar as permanências materiais na baixada da Saracura e a relação dessa antiga comunidade com a paisagem ao redor.
\end{abstract}

Palavras-chave: paisagem biopolítica, lugar de persistência, território, cartografia-histórica, córrego saracura.

\section{Rastros de un palenque de São Paulo: un análisis del paisaje arqueológico del barrio de Bixiga}

Resumen: Ante la destrucción material de las ciudades, con el constante desmantelamiento del patrimonio arqueológico y arquitectónico, las viejas calles permanecen protegidas por la necesidad diaria de uso público como pasaje. Buscamos en el paisaje del barrio de Bixiga las marcas de la antigua población de quilombolas que ocuparon las orillas del arroyo Saracura entre los siglos XVIII y XIX. A través del análisis de la cartografía histórica de la ciudad de São Paulo, buscamos rescatar las permanencias materiales en las tierras bajas de Saracura y la relación de esta antigua comunidad con el paisaje circundante.

Palabras-clave: paisaje biopolítico, lugar de persistencia, territorio, cartografía histórica, corriente saracura.

\footnotetext{
${ }^{1}$ Graduado em Ciências Sociais (Antropologia) pela UNESP de Araraquara e Mestre em Arqueologia pelo MAE- Museu de Arqueologia e Etnologia da USP. E-mail: arqueoaless@yahoo.com. ORCID: https://orcid.org/0000-0002-8022-7234
} 
Artigo | Vestígios de um quilombo paulistano: uma análise da paisagem arqueológica do bairro do Bixiga (LIMA, Alessandro Luís Lopes de)

\title{
Vestiges of a quilombo in São Paulo: an analysis of the archeological landscape of the Bixiga neighborhood
}

\begin{abstract}
Faced with the material destruction of cities, with the constant dismantling of archaeological and architectural heritage, the old streets remain protected by the daily need for public use as a passage. We seek in the landscape of the neighborhood of Bixiga, the marks of the old quilombola population that occupied the banks of the Saracura stream between the eighteenth and nineteenth centuries. Through the analysis of the historical cartography of the city of São Paulo, we seek to rescue the material permanences in the Saracura lowland and the relationship of this old community with the surrounding landscape.
\end{abstract}

Keywords: biopolitical landscape, place of persistence, territory, historical cartography, saracura stream.

\section{Introdução}

Há na sociedade brasileira diferentes formas de ocupação do solo. Em oposição às formas regradas pela legislação, temos as ocupações "espontâneas", como são as favelas nas grandes cidades. Nesses locais, a ausência da imposição das normas urbanística permitiu a formação de uma configuração espacial diferenciada. O modelo de urbanização de áreas periféricas brasileiras, com grandes quarteirões contornados por largas avenidas, de onde derivam ruas de acesso local que mais adiante se tornam vielas estreitas e becos, possui semelhanças com as configurações urbanas africanas (ver figuras 1 e 2) (WEIMER, 2014, p. 256-258).

No início do século $X X$, a região da Saracura era conhecida como a "pequena África" e a sua ocupação formava uma linha de habitações nas margens do córrego Saracura, conforme publicação do jornal Correio Paulistano de 3 de outubro de 1907. Animais soltos, crianças seminuas preparando gaiolas e homens velhos com seus cachimbos, davam ao lugar "ares do Congo" (CASTRO, 2008, p. 57-58). A região do Quilombo Saracura foi um dos berços paulistano do samba de bumbo e do batuque. 0 samba de roda em um primeiro momento e depois os cordões carnavalescos, eram práticas culturais que se tornaram expressões da negritude paulistana no século XIX e início do XX. É provável que da dissidência da torcida do antigo time de futebol da Saracura, o Cai-Cai, tenha surgido o cordão carnavalesco Vai-Vai. O Cai-Cai carregava as cores preta e branca, as mesmas da atual escola de samba Vai-Vai, herdeira direta desse legado. Na primeira metade do século passado, além da torcida de futebol, eram organizados choros e sambas na comunidade da Saracura (LUCENA, 1984, p. 77; CASTRO, 2008, p. 76-77). 


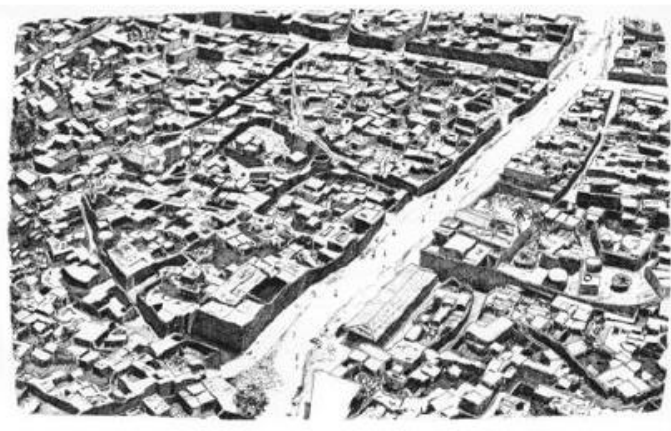

Fig. 1 Cidade de Kano - Nigéria. Fonte (WEIMER, 2008; 2014)

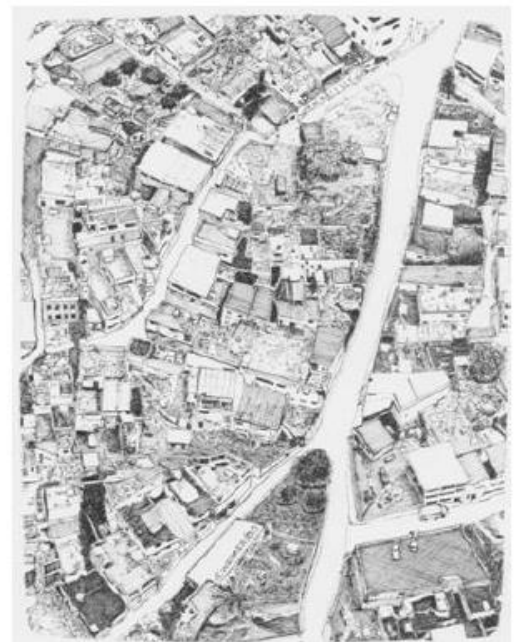

Fig. 2 Favela do Itararé (complexo do Alemão) Rio de Janeiro Fonte (WEIMER, 2008; 2014)

Para Muniz Sodré (2002), o entendimento das formas sociais de grupos relacionados à diáspora africana, exige uma perspectiva que olhe para o contato e a comunicação nas relações de coexistência, pluralidade e diferenças, frente à dominação. O terreiro de candomblé, tão presente e associado ao samba na baixada da Saracura (ALEXANDRE, 2015; 2017), é um foco de potência social para o negro do Bixiga, já que engendra sua existência e sua cultura em uma realidade onde a cidadania sempre foi limitada. Através desse terreiro que se impõe ao espaço eurocêntrico, alcançamos alguns traços da história das classes populares brasileiras (SODRÉ, 2002).

Os antigos caminhos da Saracura aparecem como uma espécie de "ruído" na malha ortogonal das ruas do bairro. Esse arruamento oficial, aparentemente tentou se impor na região do antigo quilombo, mas sem muito sucesso. Como afirma o arqueólogo português Manuel Teixeira, a comparação cartográfica pode nos revelar contínuas sobreposições, rasuras e acréscimos sobre a paisagem antiga, mas também persistências de formas urbanas passadas. A arqueologia da cidade busca ler essas marcas do passado, onde a irregularidade das ruas pode nos revelar suas origens e evolução. Compreendendo que toda cartografia é ideológica, uma construção do cartógrafo, consideramos que questões raciais distorceram esses mapas antigos, escondendo os espaços informais que não se inscreviam na ordem imposta pelas elites econômicas. O posicionamento de setores excluídos e marginalizados na estratificação social acabou refletindo na invisibilidade destes nas representações cartográficas (TEIXEIRA, 2015). 
Artigo | Vestígios de um quilombo paulistano: uma análise da paisagem arqueológica do bairro do Bixiga (LIMA, Alessandro Luís Lopes de)

\section{Território e História Cultural}

O espaço total de uma sociedade na paisagem é o território, sendo que foi nele em que interações homem-natureza se estabeleceram com o passar do tempo. Esse território, tal como um artefato que possui uma história ou um ciclo de vida ${ }^{2}$, está posto no registro das interações da sociedade sobre a terra, podendo ser reconstruído sistematicamente. No ciclo de vida, reúne-se as dimensões espaciais, temporais e materiais do território, relativos à terra, aos recursos materiais e aos artefatos. 0 território enquanto conjunção de objetos levanta trajetórias únicas, tem sua origem na história natural da terra e na história social do uso de seus recursos (ZEDEÑO, 1997).

Como um artefato, a cidade é um bem cultural, construído exclusivamente por mãos humanas (MENESES, 2006). Para Muniz Sodré (2002), o território nos revela a história do meio urbano, através dos seus habitantes e de como estes ordenaram suas relações com a terra, a água, o cosmo e com outros humanos. O território é um espaço exclusivo e organizado para as trocas comunitárias, necessárias à identidade dos grupos. O território se refere à demarcação de um espaço, perante a alteridade de outros. Um grupo é localizado territorialmente e sua permanência reconhecida, quando identificamos suas particularidades, ações simbólicas e culturais. O território particulariza o lugar, traçando fronteiras e dando corpo à ação dos sujeitos. Enquanto o espaço pode ser pensado como um sistema de definição de posições onde todo corpo ocupa qualquer lugar, o território é definido por suas singularidades, se tornando um lugar de "jogo", uma sistematização das regras de movimentação humana (SODRÉ, 2002, p. 23).

Em todo Brasil o território negro será marcado pela perseguição da sociedade colonial. Na escravidão colonial o negro foi associado à barbárie e à sub-humanidade e, após a abolição, o trabalho livre não significará nenhuma emancipação para essa população. Enquanto o negro no meio rural do período colonial era reprimido pelo feitor, o escravizado urbano passou a ser perseguido pelo aparato oficial, a força policial (MOURA,1988, p. 233). Raquel Rolnik vê nessa relação um apartheid, em que através da

\footnotetext{
${ }^{2}$ (SCHIFFER, 1972).
} 
Artigo | Vestígios de um quilombo paulistano: uma análise da paisagem arqueológica do bairro do Bixiga (LIMA, Alessandro Luís Lopes de)

descriminação e do racismo, quase sempre se buscou não reconhecer esses lugares históricos (ROLNIK, 1989, p. 16).

Abaixo, transcrevemos o texto já mencionado do jornal Correio Paulistano de 03 de outubro de 1907, mostrando aspectos humanos e naturais desse território negro da Saracura. Ainda que racista e preconceituoso, o artigo revela um pouco da vida cultural desse Bixiga antigo. Nos chama atenção ao detalhe da influência da autoridade religiosa do lugar (Pai Antônio) em outras localidades de São Paulo, as referências topográficas aos vales e também a revelação da fileira de casas nas margens do córrego. Essa última informação nos passa uma referência do locus populacional desse antigo quilombo.

\section{A Saracura}

É um pedaço da África. As relíquias da pobre raça impelida pela civilização cosmopolita que invadiu a cidade, ao depois de 88, foi dar ali naquela furna. Uma linha de casebres borda as margens do riacho. O Valle é fundo e estreito. Poças d'agua esverdeada marcam os logares donde sahiu a argila transformada em palacetes e residências de luxo.

Cabras soltas na estrada, pretinhos semi-nus fazendo gaiolas, chibarros e longa barba ao pe' dos velhos de carapinha embranquecida e lábio grosso de que pende o cachimbo, dão aquelle recanto uns ares do Congo.

Alli Pae Antonio, cujas mandingas celebram os supersticiosos de Pinheiros, de Santo Amarão, da várzea do Tasbôa, pratica os seus mysterios e tange o urucungo, apoiando ao ventre rugoso e despido a cabaça resonanta. As casas são pequenas; as portas baixas. Há pinturas enfumaçadas pelas paredes esburacadas. A mobília, caixas velhas e toros de pau, sobre ser pobre, é sórdida. E ali vão morrendo aos poucos - sacrificados pela própria liberdade que não souberam gosar, recosidos pelo álcool e estertorando nas angustias do brightismo que os dizima, eliminados pela elaboração anthropologica da nova raça paulista - os que vieram nos navios negreiros, que plantaram o café, que cevaram este solo de suro e lágrimas, acumulados ali, como rebutalho da cidade, no fundo lôbrego de um valle. (CASTRO, 2008, p. 57-58)

Os Campos do Bixiga correspondiam a todo espaço entre às Ruas Santo Amaro e da Consolação no século XIX, lugar com densa vegetação e onde perseguiam os foragidos da escravidão colonial. A densa mata da região do Caanguçu, no atual bairro 
Artigo | Vestígios de um quilombo paulistano: uma análise da paisagem arqueológica do bairro do Bixiga (LIMA, Alessandro Luís Lopes de)

da Bela Vista (Bixiga), e seus vales nas divisas das propriedades rurais, ofereciam refúgio seguro aos fugitivos da escravidão (FREITAS, 1978, p. 21; WISSENBACH, 1998, p. 153). Segundo os estudos de Nuto Santana, no século XVIII a preocupação com os quilombolas nos arredores de São Paulo era um assunto presente nas atas da Câmara Municipal (BRUNO, 1954, p. 358).
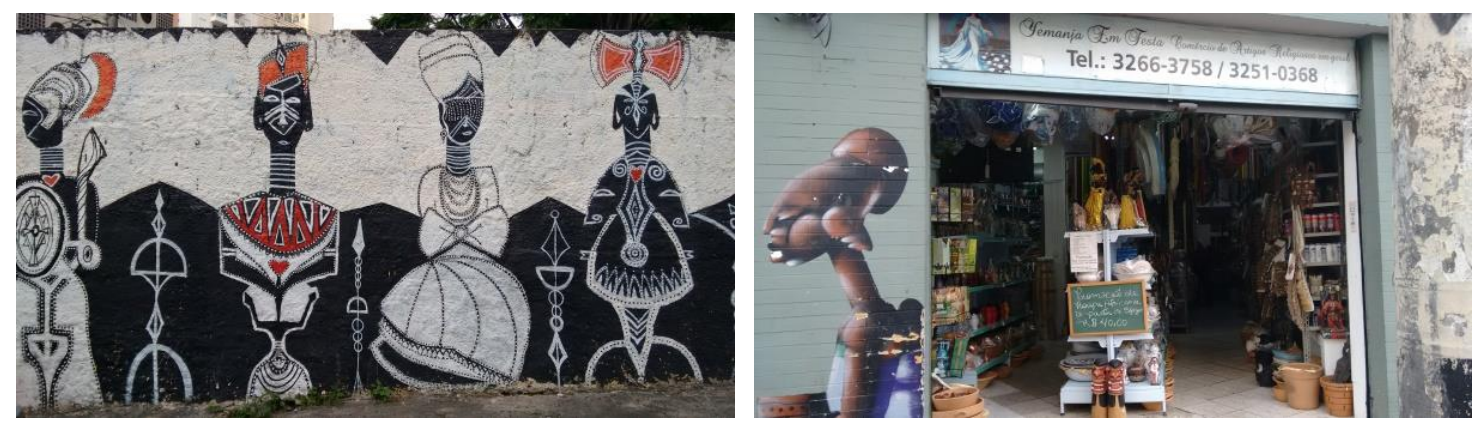

Figuras 3 e 4. Referências à etnicidade afro-brasileira nas ruas da região da Saracura. Um mural grafitado com os Orixás e uma loja de artigos religiosos das religiões de matrizes africanas (fontes: Alessandro de Lima, mar./2018).

O registro mais antigo da reclamação do poder público contra a população negra que se juntavam em malocas pelos arredores da cidade de São Paulo é de 1748 , criticando seus batuques e alertando para o perigo do contato das escravizadas domésticas com os aquilombados. Elas poderiam passar informações cruciais e auxiliar os quilombolas em suas investidas, por isso recomendava-se aos seus proprietários que não as deixassem ir além dos limites da cidade. Existem ordens no ano de 1787 para o fechamento do comércio após as 20 horas, para que os quilombolas não agissem na região central da cidade; em 1791 aparecem novas ordens para o combate com armas de fogo aos negros, que vinham causando desordens em São Paulo (BRUNO, 1954, p. 358).

O historiador Ernani S. Bruno identificou nas Atas da Câmara Municipal, um requerimento de 1831, pedindo ao poder público municipal para fechar as passagens por onde corria o Rio Anhangabaú (o Saracura é afluente desse rio e frequentemente era chamado de Anhangabaú), por que nas margens habitavam ladrões e escravizados foragidos e aquilombados (BRUNO, 1954, p. 738; LUCENA,1984, p. 24). Eram comuns nesse período as restrições públicas aos negros, como a proibição de andarem armados 
Artigo | Vestígios de um quilombo paulistano: uma análise da paisagem arqueológica do bairro do Bixiga (LIMA, Alessandro Luís Lopes de)

com paus e pedras e a que obrigavam os moradores cortar o mato nas praças, evitando esconderijos para os fugitivos (DIAS, 1984, p. 120).

O "quadrilátero negro" do bairro, lugar histórico da antiga comunidade da Saracura, está localizado entre as Ruas Rocha, Almirante Marques Leão e a Rua Una, tendo como base a Avenida 9 Julho. No Bixiga, além destas, outras duas ruas tem seu nome diretamente relacionado à história do povo negro, a Rua Treze de Maio e a Rua da Abolição (CASTRO, 2008, p. 62). Hoje em dia, essas ruas associadas à história negra do bairro são reconhecidas pela população através do seu calendário religioso. Na Festa e Procissão de Ogum da Vai-Vai, dedicada a Ogum-São Jorge e que abre os trabalhos para o próximo carnaval. Todo ano sai uma procissão da quadra da Vai-Vai carregando uma imagem de São Jorge, em direção à Igreja Nossa Senhora Achiropita, na Rua Treze de Maio. Depois ela passa pelo Terreiro do Pai Francisco D’Osun, na Rua Almirante Marques Leão e retorna à quadra da escola, através da Rua São Vicente (ALEXANDRE, 2015).
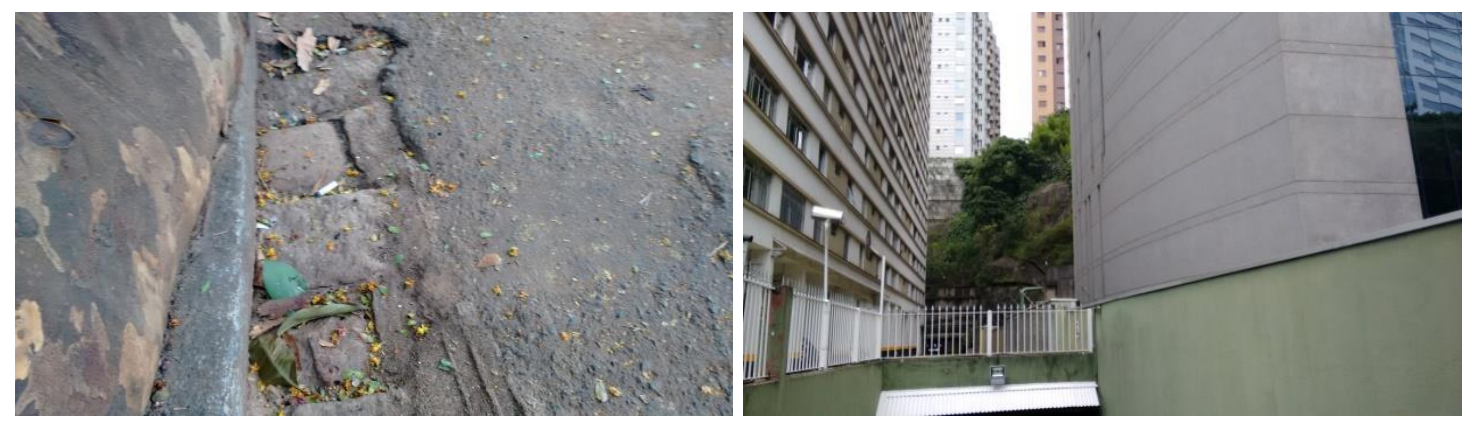

Figura 5. Os estratos da Saracura. Na Rua Dr. Lourenço Granatto, aparecem paralelepípedos de um calçamento antigo, sob o asfalto contemporâneo (fonte: Alessandro de Lima, mar. /2018). Figura 6. A paisagem natural do antigo Vale da Saracura ainda se impõe por trás dos prédios da Avenida 9 de Julho (fonte: Alessandro de Lima, mar./2018).

O logradouro onde hoje se encontra a quadra da Escola de Samba Vai-Vai, marco geográfico do "Quadrilátero da Saracura", em uma perspectiva arqueológica pode ser considerado um lugar de persistência, já que por gerações permanece sua significação e territorialidade. Lugares de persistência são aqueles que por um longo período, foram repetidamente utilizados na ocupação de uma região. Não são apenas sítios de concentração material ou paisagem, mas a conjunção de comportamentos humanos específicos em uma mesma paisagem. O lugar de persistência não depende de nenhuma 
Artigo | Vestígios de um quilombo paulistano: uma análise da paisagem arqueológica do bairro do Bixiga (LIMA, Alessandro Luís Lopes de)

característica cultural específica, mas só é definido através da presença da materialidade (SCHLANGER, 1992; ZEDEÑO, 1997).
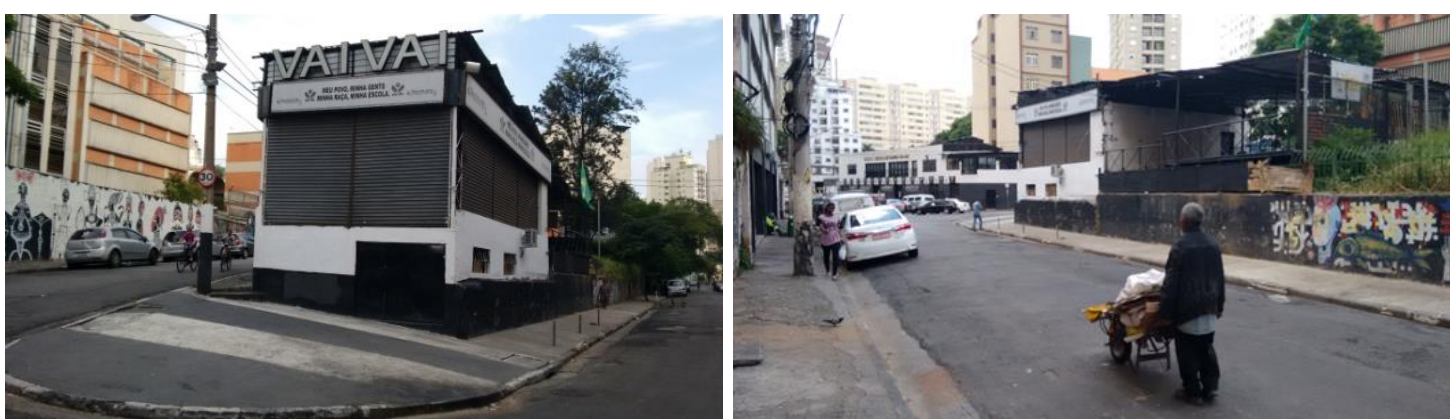

Figuras 7 e 8. Local das festas da Escola de Samba Vai-Vai. Na esquerda, começa a Rua Dr. Lourenço Granatto, à direita, a Rua Cardeal Leme. Na Figura 8, vemos a Rua Cardeal Leme (por onde hoje corre canalizado o córrego da Saracura grande) em direção à Avenida 9 de julho (fontes: Alessandro de Lima, mar. /2018).

\section{Analisando a cartografia histórica paulistana (séc. XIX-XX)}

Através da cartografia histórica podemos compreender a morfologia urbana, que somada à observação contemporânea da cidade, nos permite visualizar suas características e sua evolução. A cartografia revela as bases que determinaram o traçado das ruas e de outros processos que deram origem aos espaços urbanos. As cidades são sínteses de diversas camadas físicas e temporais acumuladas e entrelaçadas (figura 5), simultaneamente presente nas ruas e nos edifícios, assim como nos usos para além das motivações originais (TEIXEIRA, 2015).
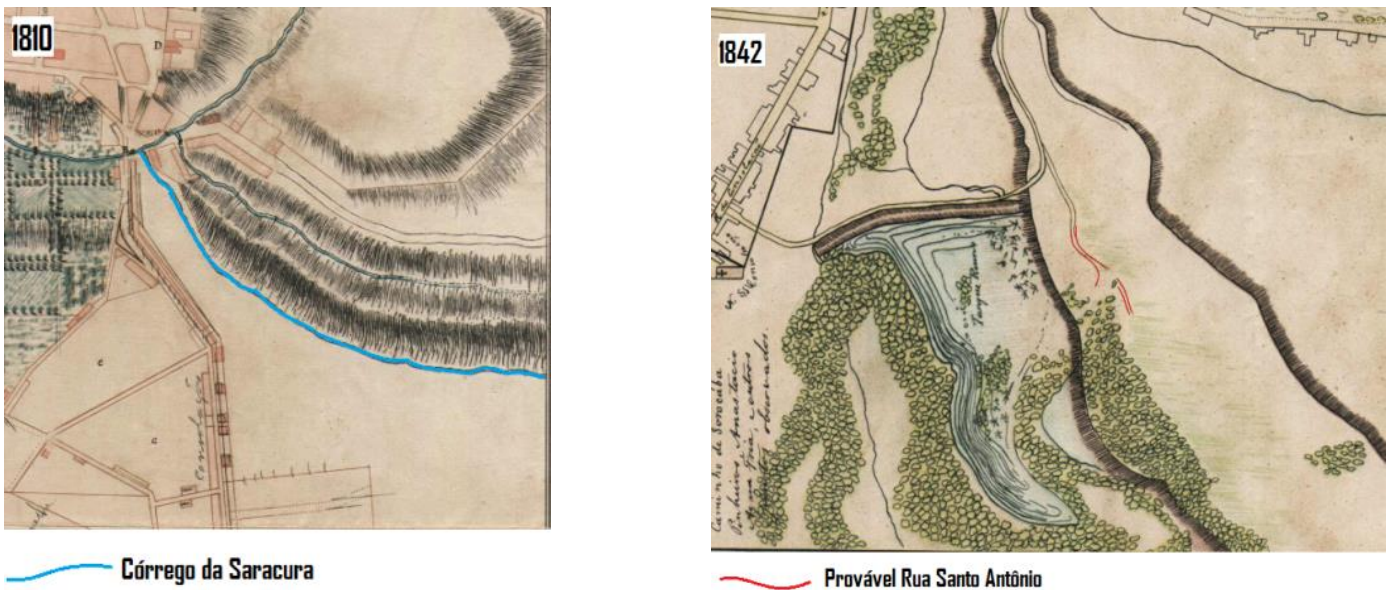

Figuras 9 e 10. (Fonte: SISTEMA DE CONSULTA DO MAPA DIGITAL DA CIDADE DE SÃO PAULO, 2018). 
Artigo | Vestígios de um quilombo paulistano: uma análise da paisagem arqueológica do bairro do Bixiga (LIMA, Alessandro Luís Lopes de)

Na imagem relativa a 1810 (figura 9), da carta Planta da cidade de São Paulo, não há qualquer menção à ocupação humana na região. A principal referência desse mapa é a abundante mata ciliar que percorria a extensão do córrego Saracura (em azul). Na Carta da capital de São Paulo de 1842 (figura 10), aparecem as primeiras referências à ação humana, como o Tanque do Reúno e um caminho incompleto, sinuoso, provavelmente relacionado ao final da antiga Rua Santo Antônio. Nesse mapa vemos a densa mata do Caanguçu contornando a antiga represa. Estes foram dois pontos referenciais na paisagem para os quilombolas da Saracura nos séculos XVIII e XIX.

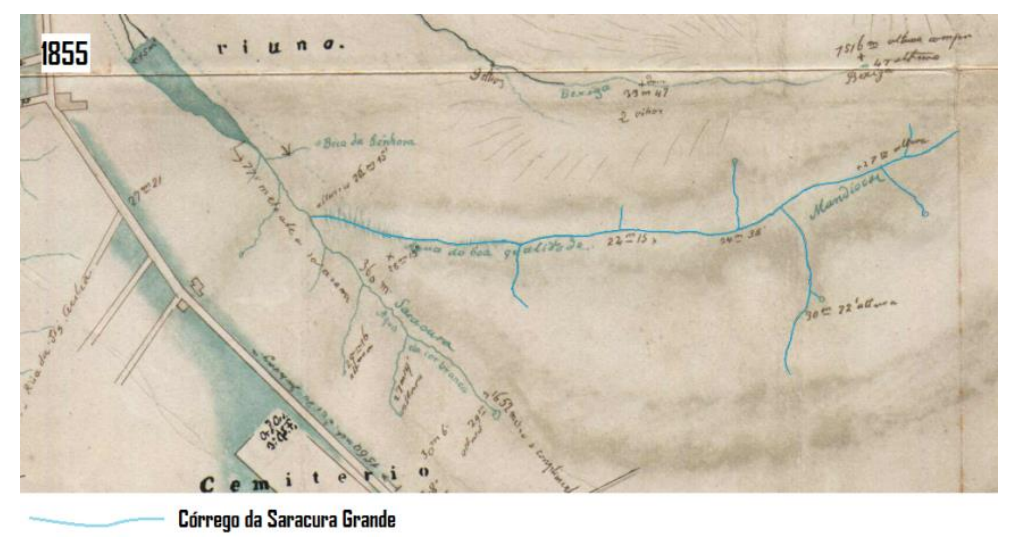

Figura 11. (Fonte: SISTEMA DE CONSULTA DO MAPA DIGITAL DA CIDADE DE SÃO PAULO, 2018).

No Mappa da imperial cidade de S. Paulo, de 1855 (figura 11) não há qualquer referência aos antigos caminhos, porém essa documentação reproduz em detalhes a bacia hidrográfica da região. Nesse mapa, observamos o Tanque do Reúno e em azul marinho, o córrego da Saracura grande e suas nascentes. Essa paisagem se encontra em simbiose com a ocupação humana da Saracura. Mesmo que não possamos enxergar diretamente a ocupação quilombola, indiretamente é possível percebe-la na formação natural, que intrinsicamente a compõe. Na paisagem, meio termo entre o natural e o cultural, também se encontra o que Pierre Bourdieu definiu por habitus, as práticas da rotina social e por onde o mundo foi experienciado (ASHMORE, KNAPP; 1999). 


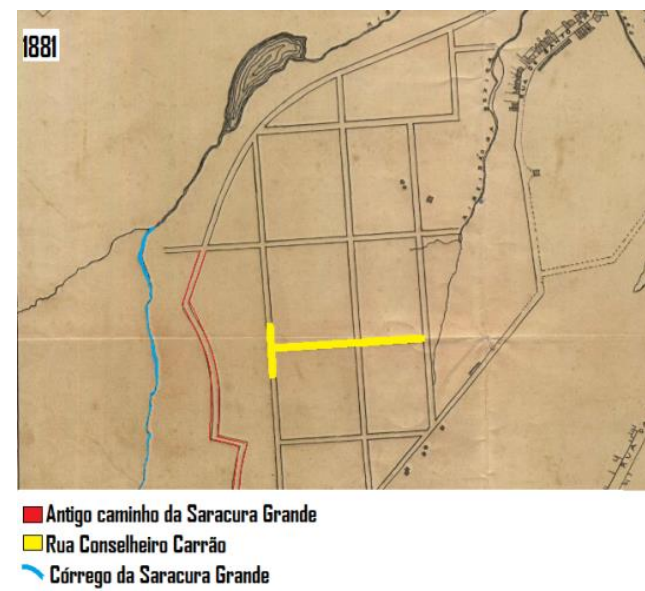

Córrego da Saracura Grande

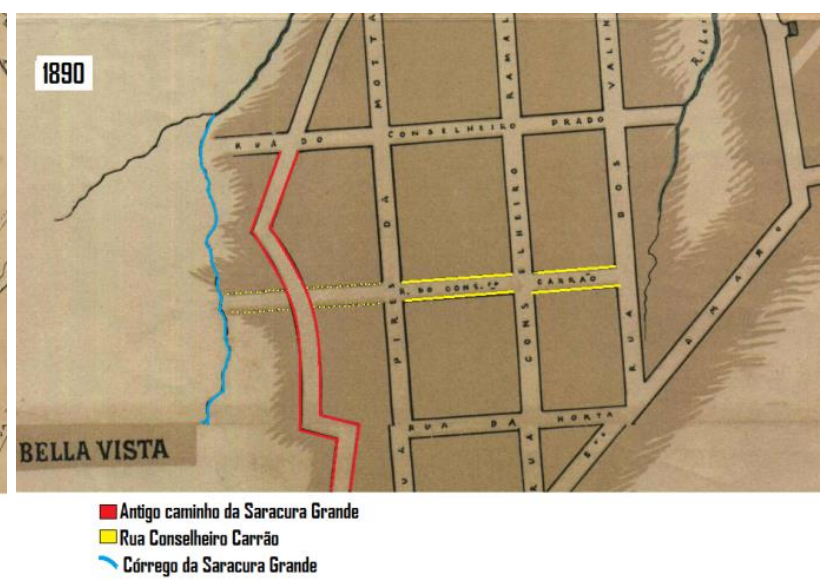

Figuras 12 e 13. (Fonte: SISTEMA DE CONSULTA DO MAPA DIGITAL DA CIDADE DE SÃO PAULO, 2018).

Na segunda metade do século XIX, começa o arruamento ortogonal no bairro do Bixiga. Isso obrigou o antigo caminho do Quilombo Saracura, até então mal representado na cartografia, a aparecer na documentação. Aparentemente havia um esforço para que a malha ortogonal de ruas se integrasse aos caminhos já estabelecidos; isso é bastante perceptível, já que essas vias eram sinuosas, contrastando com a lógica cartesiana dos arruamentos. Nos mapas de 1881 e 1890 (figuras 12 e 13), em azul, observamos o córrego da Saracura grande. Ao seu lado, em vermelho, vemos uma rua sem forma definida, a Almirante Marques Leão (antigo caminho da Saracura). A sinuosidade nessa rua, observada desde a carta de 1842 (figura 10), provavelmente ocorria devido aos morros e acidentes geográficos do Vale da Saracura ${ }^{3}$. É percebido que, quando a malha ortogonal se aproxima da região da Saracura, ela é interrompida por outra formação. A Rua Conselheiro Carrão (em amarelo), na carta intitulada Planta da cidade de São Paulo levantada pela Companhia Gantareira e Esgotos, de 1881 (figura 12), aparece recuada, terminando na altura da Rua Treze de Maio. Porém em 1890, uma década depois, na Planta da capital do Estado de S. Paulo e seus arrabaldes (figura13), a Rua Conselheiro Carrão aparece pontilhada e prolongada, cruzando a Almirante Marques Leão e chegando até o córrego da Saracura; aparentemente isso demonstra alguma intensão em avançar sobre o território dos quilombolas da Saracura.

\footnotetext{
${ }^{3}$ A Rua Almirante Marques Leão foi retificada em 1919 (Lei 2.181/1919) e sua oficialização se deu em 1981 (Decreto Lei 17.522 de 14/09/1981), fonte:

https://dicionarioderuas.prefeitura.sp.gov.br/logradouro/rua-almirante-marques-de-leao
} 
Artigo | Vestígios de um quilombo paulistano: uma análise da paisagem arqueológica do bairro do Bixiga (LIMA, Alessandro Luís Lopes de)

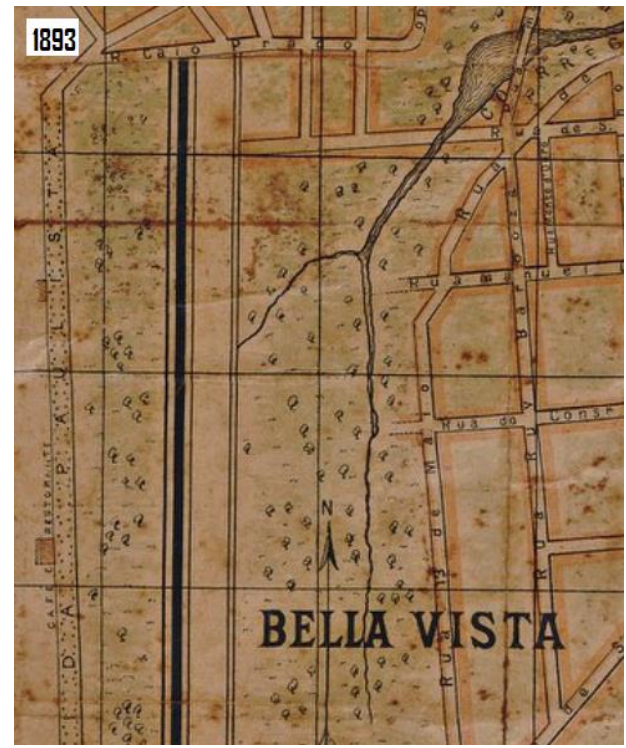

Figura 14. (Fonte: SISTEMA DE CONSULTA DO MAPA DIGITAL DA CIDADE DE SÃO PAULO, 2018).

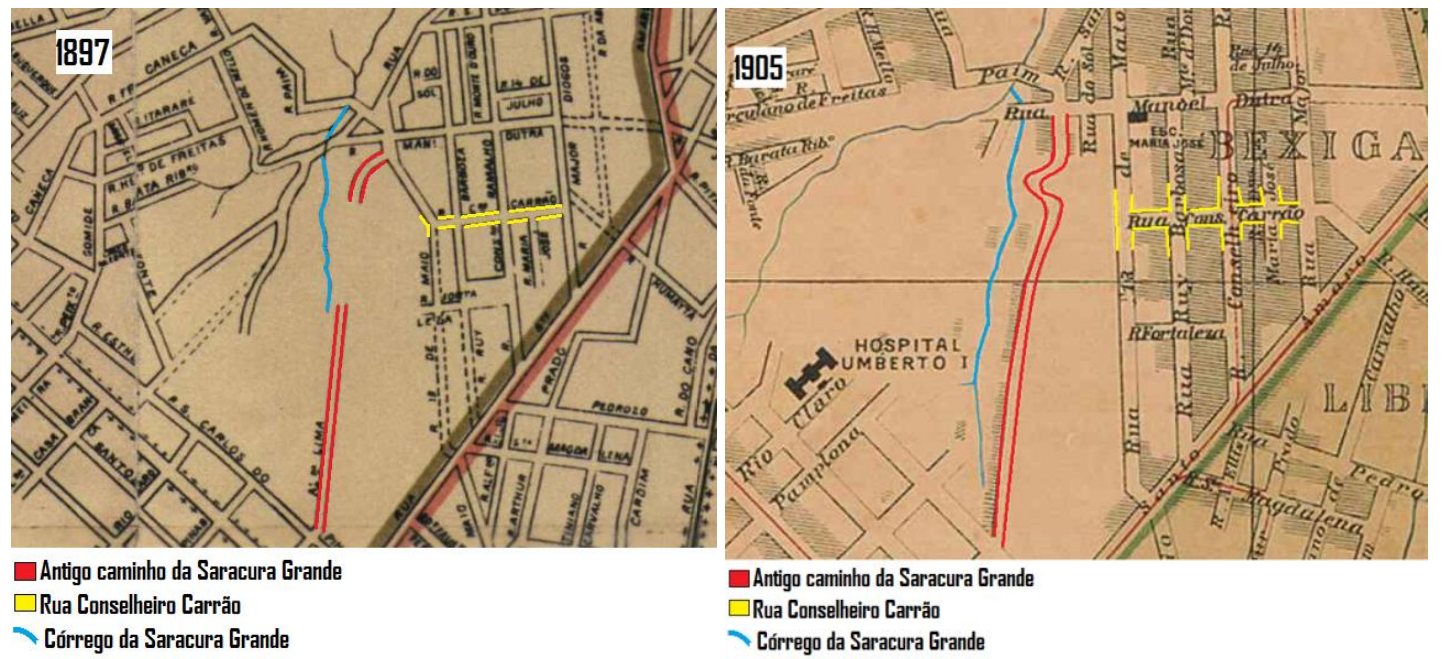

Figuras 15 e 16. (Fonte: SISTEMA DE CONSULTA DO MAPA DIGITAL DA CIDADE DE SÃO PAULO, 2018).

No mapa de 1893, chamado Planta da cidade de São Paulo com indicação dos primeiros edifícios públicos (figura 14), é possível visualizar o desenho de pequenas árvores e a cor esverdeada, no entorno do córrego Saracura. Essa é mais uma representação das Matas do Caanguçu na documentação cartográfica. Ela percorre a extensão do córrego da Saracura grande e chega até o Tanque do Reúno. Essa vegetação era uma mata ciliar ao curso d'água, constituía fonte de alimento e recursos hídricos para os quilombolas. Ela garantiu por aproximadamente dois séculos o sustento da antiga comunidade da Saracura. 
Artigo | Vestígios de um quilombo paulistano: uma análise da paisagem arqueológica do bairro do Bixiga (LIMA, Alessandro Luís Lopes de)

No mapa de 1897, chamado Planta geral da capital de São Paulo (figura 15), a Rua Almirante Marques Leão/ Caminho da Saracura se encontra desmembrada e a Rua Conselheiro Carrão (em amarelo), recua novamente até a Rua Treze de Maio. No prolongamento da Rua Manoel Dutra, temos alguns caminhos relativos ao outros prováveis trechos da Saracura (a Saracura pequena).

No mapa de 1905 (figura 16), intitulado Planta geral da cidade de S. Paulo adoptada pela Prefeitura Municipal para uso de suas repartições, esses caminhos sinuosos desaparecem no registro cartográfico, demonstrando indefinição em relação às ruas da região. Porém, na carta de 1905, a curva que aparece desde o mapa de 1842 permanece no antigo Caminho da Saracura, posteriormente chamado Rua Almirante Marques Leão (em vermelho).

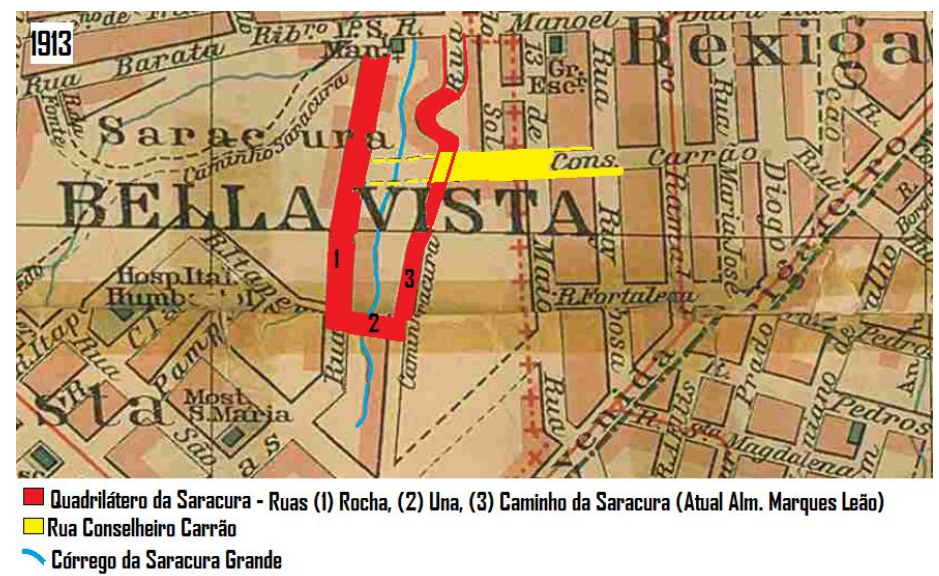

Figura 17. (Fonte: SISTEMA DE CONSULTA DO MAPA DIGITAL DA CIDADE DE SÃO PAULO, 2018).

Na carta de 1913, a Planta da cidade de São Paulo (figura 17), já visualizamos o padrão das ruas que começa a se estabelecer na região. O Caminho da Saracura/ Rua Almirante Marques Leão (3) se mantém e também sua sinuosidade. Aqui, a Rua Conselheiro Carrão volta a cruzar com o antigo Caminho da Saracura/ Almirante Marques Leão, dessa vez até ultrapassando o córrego. Na legenda do mapa original, os pontilhados indicam as "ruas projetadas". 


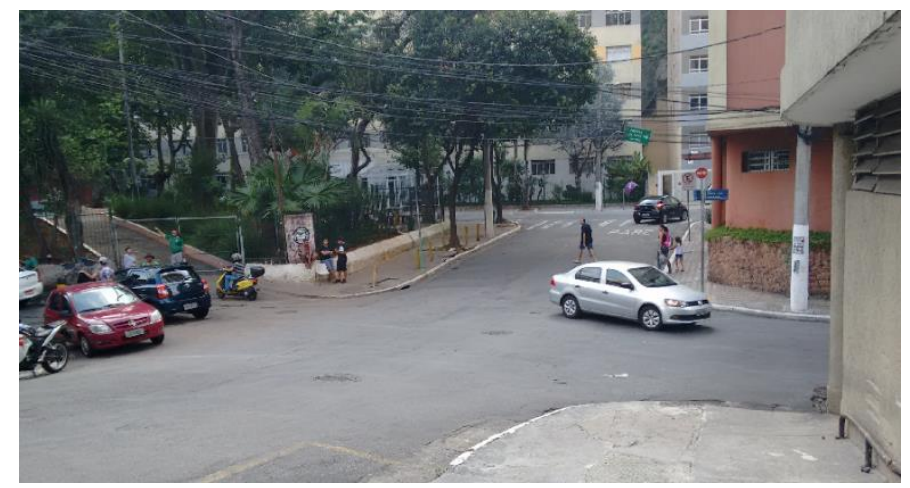

Figura 18. Rua Una (na fig. 17, é a referencia $n^{\circ} 2$ ). Local das nascentes da Saracura grande e onde começa a atual Rua Cardeal Leme. Esse é um ponto geográfico e paisagístico referente ao antigo quilombo (Fonte: Alessandro Lima, 2018).

O córrego, em azul, separa dois grupos de casas no início do século XX. Nos mapas de 1905 (figura 16) e 1916 (figura 19) é possível visualizar manchas escuras, que provavelmente correspondem às partes habitadas do terreno. Elas estão separadas pelo córrego da Saracura grande, tal como referencia o jornal Correio Paulistano de 03 de outubro de 1907, afirmando que as casas da Saracura se encontravam às margens desse córrego (CASTRO, 2008, p. 57-58).

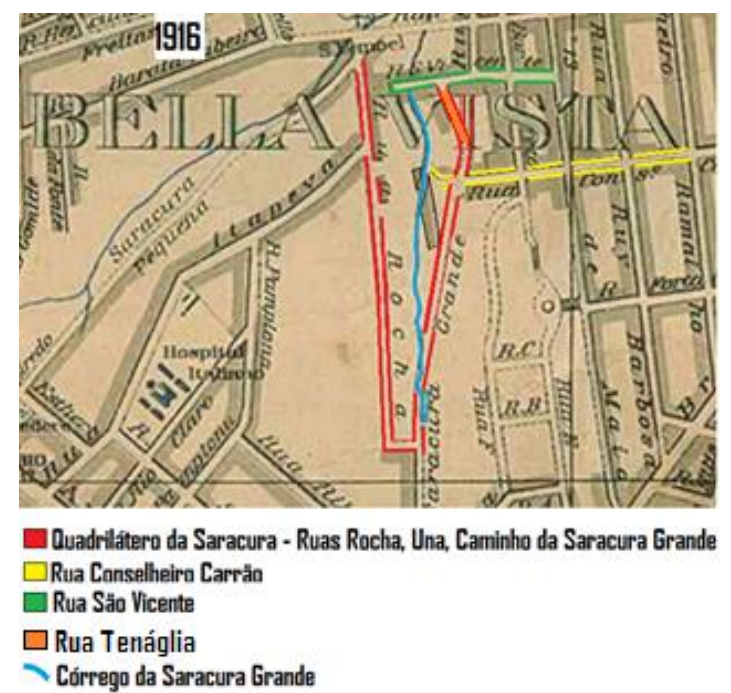

Figura 19. (Fonte: SISTEMA DE CONSULTA DO MAPA DIGITAL DA CIDADE DE SÃO PAULO, 2018).

Na Planta da cidade de São Paulo levantada pela divisão cadastral da $2^{\circ}$ Seç̧ão da Directoria de Obras e Viação da Prefeitura Municipal, carta de 1916, a Rua Conselheiro Carrão (amarelo) novamente recua para antes do Córrego Saracura. É perceptível a inconstância nas ruas na região do antigo quilombo, onde se impôs o 
Artigo | Vestígios de um quilombo paulistano: uma análise da paisagem arqueológica do bairro do Bixiga (LIMA, Alessandro Luís Lopes de)

traçado original dessa ocupação perante as investidas da malha ortogonal do arruamento público. Porém nessa carta (figura 19), no final da Rua Conselheiro Carrão é referenciada uma curva para a direita, indicando que existe um prolongamento desse caminho, que posteriormente na verdade vai se tornar à Rua Dr. Lourenço Granato. Essa indefinição é percebida ainda no Mappa Topográfico do Município de São Paulo, de 1930 (figura 20), em que aparece um córrego da Saracura que corria a céu aberto. Nessa carta começa a aparecer a Rua Dr. Lourenço Granato, porém ainda incompleta. Seu final será no encontro com o córrego da Saracura, onde hoje está o barracão de festas da VaiVai (figura 7). No mapa de 1930, essa rua aparece interrompida por dois lotes e uma edificação, que depois irão desaparecer para abrir caminho definitivo até o encontro com o córrego da Saracura grande.
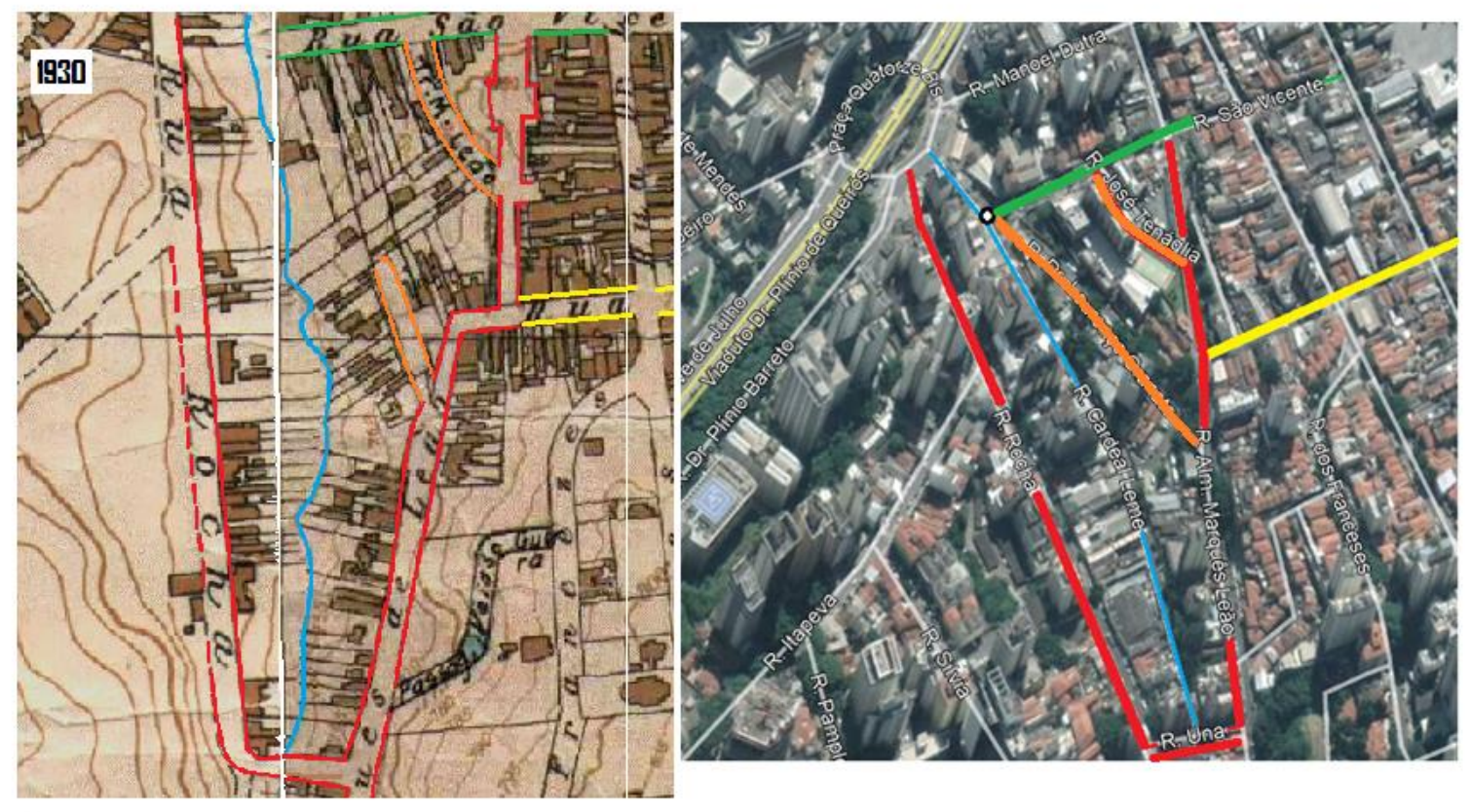

- Rua Dr. Lourenço Granato Rua Tenáglia

- Rua Cardeal Leme (Segue o antigo curso da Saracura Grande, que hoje corre pelo subterrân

O Escola de Samba Vai-Yai

- Quadrilattero da Saracura • Rua Una, Rua Rocha e o antigo Caminho da Saracura Grande (atual Alm. Marques Leão)

Rua Conselheiro Carrão

- Rua Säo Vicente

Figura 20. (Fonte: SISTEMA DE CONSULTA DO MAPA DIGITAL DA CIDADE DE SÃO PAULO, 2018). Figura 21. (Fonte: Google Earth, 2019).

No "quadrilátero da Saracura" (figura 21), que tem como limites as Ruas Rocha, Almirante Marques Leão, Una e a Avenida 9 Julho (CASTRO, 2008, p.62), há em seu interior duas ruas irregulares, a Rua José Tenáglia (em laranja), terminando na Rua São Vicente (em verde) e a Rua Dr. Lourenço Granato (em laranja), que aparece na documentação apenas a partir da carta de 1916. 

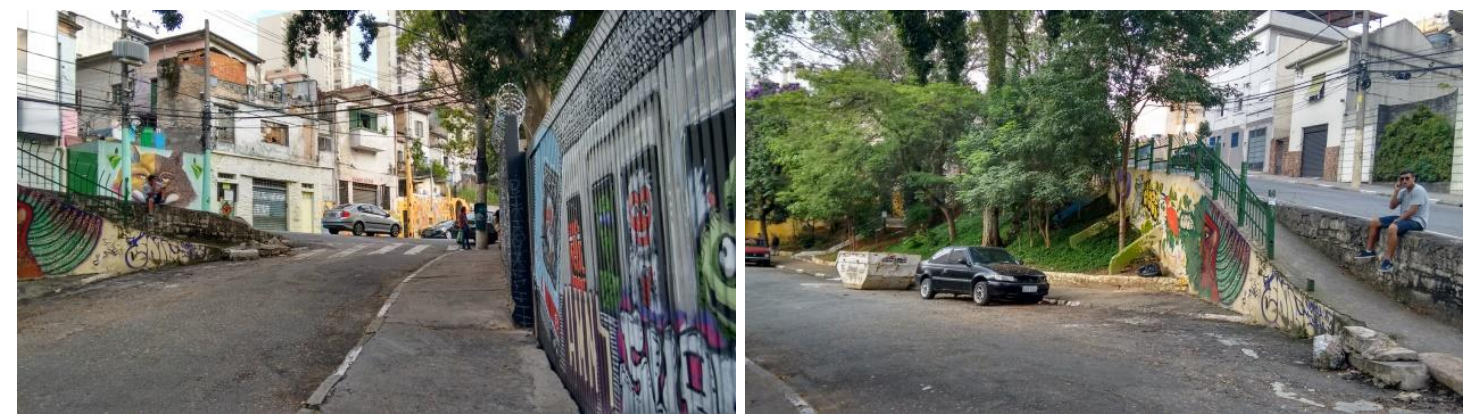

Figuras 22 e 23. Local do encontro da Rua Dr. Lourenço Granato com a Rua Almirante Marques Leão. Área de ocupação da antiga população do Quilombo da Saracura (fonte: Alessandro de Lima, mar./2018).

A Rua Dr. Lourenço Granato é paralela ao córrego da Saracura (R. Cardeal Leme). Acreditamos ser este, um caminho remanescente do antigo quilombo. Nas figuras $22 \mathrm{e}$ 23, vemos o encontro das Ruas Dr. Lourenço Granato com a Almirante Marques Leão. Na estrutura das propriedades dessa área na carta de 1930 (figura 20), há lotes estreitos e longos, terminando nas margens do córrego da Saracura grande. Acreditamos que essa distribuição espacial deve estar diretamente relacionada ao locus populacional do antigo Quilombo da Saracura.

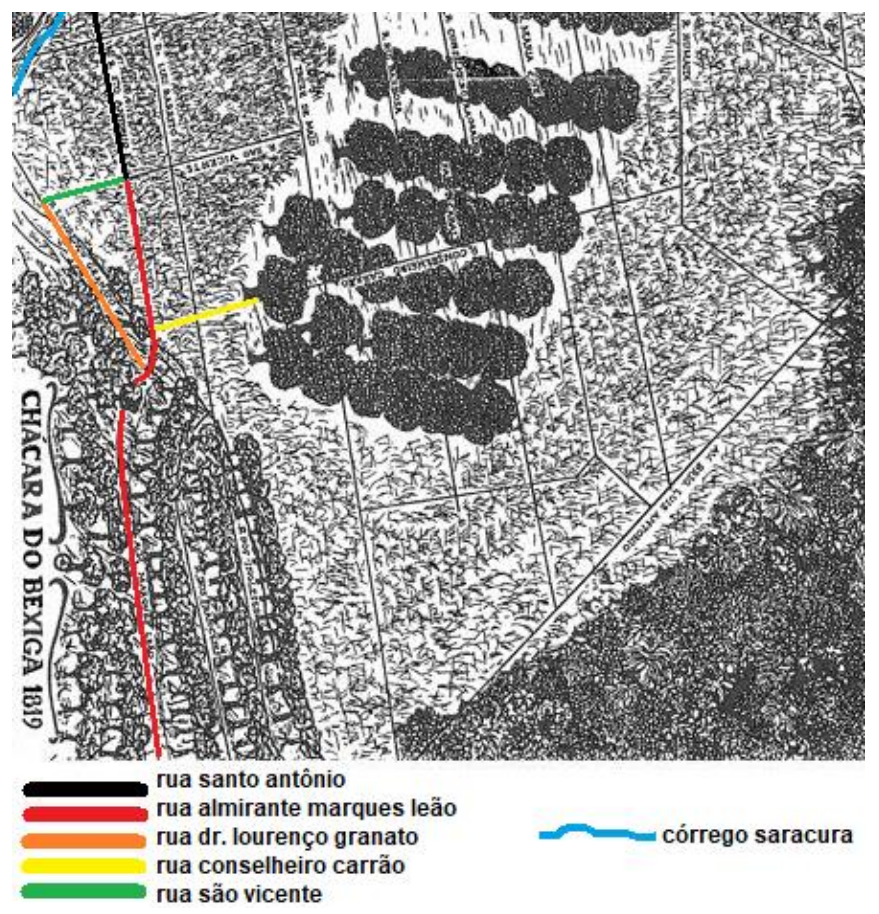

Figura 24. Um croqui da Chácara do Bexiga, de 1819 (fonte: Acervo da EMURB).

No croqui da Chácara Bexiga em 1819 (figura 24), o futuro arruamento do bairro foi desenhado, sobreposto ao desenho. Podemos visualizar a possível localização da futura Rua Dr. Lourenço Granato (em laranja, figura 24), em meio à vegetação arbórea. 
Artigo | Vestígios de um quilombo paulistano: uma análise da paisagem arqueológica do bairro do Bixiga (LIMA, Alessandro Luís Lopes de)

Não visualizamos o córrego da Saracura grande e nem suas nascentes nessa imagem. Talvez por estar relacionada à ocupação original da Saracura, a Rua Dr. Lourenço Granato foi ignorada na documentação cartográfica oficial durante os séculos XIX e início do XX. Essa rua foi reconhecida como via oficial apenas na segunda metade do século $X X$, pela Lei 4371/53, pelo Decreto $n^{\circ} .11 .341$ de 24/09/1974, com sua oficialização ocorrendo com o Decreto $n^{\circ} .17 .522$ de 14/09/19814.

\section{Discussão}

A constante indefinição das ruas no referido "quadrilátero negro" da Saracura, observada na cartografia histórica desde a carta de 1881, expõem os dilemas sociopolíticos e econômicos da urbanização no bairro. Aparentemente a malha ortogonal tentou avançar sobre a ocupação da Saracura, porém não obteve êxito, provavelmente devido a uma legislação urbana ambígua, surgida na virada do século XIX para o XX. Essa legislação ao mesmo tempo em que exigia regras rígidas em áreas urbanizadas, deixava livre o desenvolvimento de ruas nos subúrbios e áreas rurais, o que favorecia aos interesses imobiliários ${ }^{5}$ (ROLNIK, 1997).

A cidade carrega as marcas da sua própria história, nelas identificamos o passado rural de zonas urbanas contemporâneas. Em suas ruas e vias, visualizamos traçados irregulares e as antigas "azinhagas". A arqueologia da cidade faz uma leitura atenta das marcas do passado e identifica nas irregularidades, suas origens, transformações e sua estrutura formal. A comparação cartográfica de diferentes momentos revelam sobreposições, mas também persistências de morfologias antigas, que normalmente mudam e ganham novos usos (TEIXEIRA, 2015).

\footnotetext{
${ }^{4}$ Fonte: https://dicionarioderuas.prefeitura.sp.gov.br/logradouro/rua-doutor-lorenco-granato

${ }^{5}$ Como observa Caio Prado Jr. (1983), essa ausência do poder público levou a constituição de alguns bairros de forma desarticulada e com distribuição desordenada. Os especuladores acabavam não fazendo os arruamentos, ou faziam apenas no papel e os repassavam a outros compradores, por preços bem mais altos. Os proprietários cuidavam apenas de seus caminhos particulares em suas propriedades. E mesmo nos bairros onde existiu algum traçado interno com critérios, estes não formavam um sistema lógico em conjunto com a cidade, fenômeno este que vemos acontecer no Bixiga. Nessas regiões a urbanização era interrompida por espaços rurais, "vazios", sem arruamentos ou acessos transitáveis (PRADO, 1983, p.7476). Claude Levi-Strauss em seu livro de memórias Saudades de São Paulo, percebe essa cidade fragmentada, com espaços rurais em meio ao urbano e uma geografia acidentada e esculpida por rios, com ruas provincianas e bondes interrompidos por carros de boi. Para o antropólogo francês, era essa inerente diversidade que fazia o encanto de São Paulo (LÉVI-STRAUSS, 1996).
} 


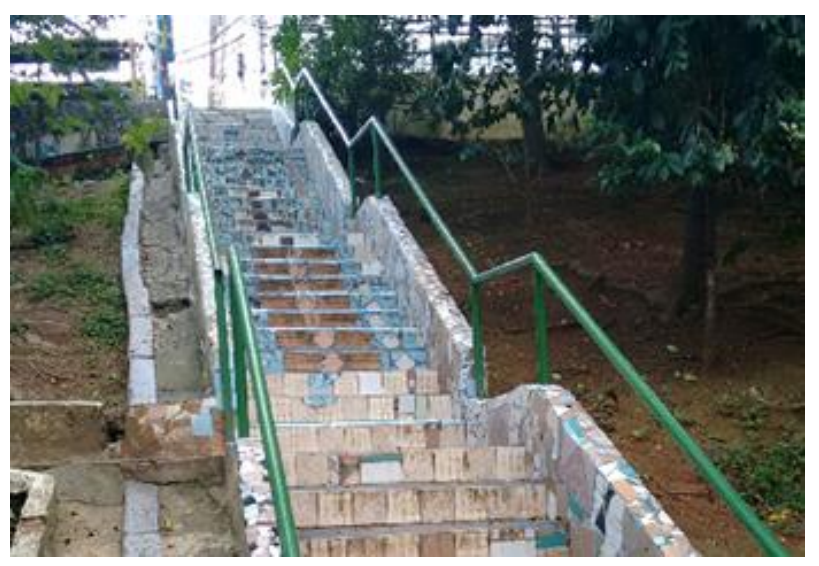

Figura 25. Hoje a Rua Conselheiro Carrão, após seu encontro com a Rua Almirante Marques Leão, se transforma em uma escadaria para pedestre, enfeitada com a arte em mosaico de ladrilhos produzida pelo artista Arieh Wagner, com descartes materiais do próprio Bixiga. A escadaria termina na Rua Dr. Lourenço Granato (fonte: Alessandro Lima, mar./2018).

Nos territórios afro-brasileiros, os assentamentos remetem às formas do urbanismo das cidades africanas, na morfologia das vielas e das ruas sinuosas, becos e "quebradas". Os conceitos mais eurocêntricos as definem como ruas "tortuosas", ou "espontâneas", porém suas formas são resultados de um longo passado de adaptação à topografia do lugar, que nada tem de irracional ou "espontâneo" (WEIMER, 2014, p. 258-259). A formação da paisagem cultural da Saracura é fruto direto da relação entre cultura material e comportamento humano, porém suas marcas são únicas, com origem na história, cultura e na agência ${ }^{6}$ dos que ali atuaram e continuam atuando.

$\mathrm{Na}$ arqueologia histórica brasileira, os estudos de Carlos Magno Guimarães compreenderam os quilombos como sítios urbanos, mesmo que estabelecidos em zonas rurais (FUNARI, 2014). Podemos dizer que uma interação em rede ${ }^{7}$ se estabelecia entre dois núcleos urbanos do município de São Paulo no século XIX, as áreas urbanizadas do triângulo histórico (e/ou da Avenida Paulista) e a Saracura. Essa rede era composta por relações sociais assimétricas, verticais, entre elites e estamentos subalternos da sociedade colonial e pós-colonial. O arqueólogo norte-americano Charler Orser Jr., compreende Palmares como um grande quilombo que nunca viveu isolado do mundo, pois se conectava em escala regional, nacional e global, através de redes socioeconômicas e materiais (ORSER, 1996; 1999). O território quilombola de uma forma geral, nunca esteve totalmente separado da sociedade colonial, muitos menos

\footnotetext{
${ }^{6}$ (HODDER; HUTSON, 2003, p. 14)

7 (ORSER, 1996; 1999)
} 
Artigo | Vestígios de um quilombo paulistano: uma análise da paisagem arqueológica do bairro do Bixiga (LIMA, Alessandro Luís Lopes de)

era apenas uma negação polarizada dessa sociedade, existiam interações econômicas e culturais entre essas duas realidades sociais (FLORENTINO; AMANTINO, 2012).

Para a elaboração de nossa análise, partimos dos princípios elencado por Zedeño (1997), onde é destacada a importância do levantamento do registro material das interações homem-terra. Para além da simples distribuição de habitações e artefatos, buscamos reconstituir as prováveis relações ambientais e sociais construídas pela antiga comunidade quilombola. Elencamos os prováveis usos dos recursos naturais e as interações sociais internas e externas à Saracura.

A ocupação às margens do córrego da Saracura grande, próximo às nascentes, assim como a localização na baixada alagável de um vale é equivalente à forma de ocupação do quilombo baiano do século XVIII, o Buraco do Tatu (WEIMER, 2014, p. 167168, 172). O arquiteto Gunter Weimer, observando a representação gráfica desse quilombo, constatou que ele se localizava dentro de uma área alagadiça, fato que dificultava a aproximação daqueles que não conheciam o terreno. Por outro lado, este é um tipo de ambiente que favorecia a fuga daqueles que habitavam a região. Essa forma de ocupação, próxima aos brejos e mangues, seria pertinente às necessidades imposta pela perseguição da sociedade colonial e também por sua riqueza energética, já que fornecia peixes e outras espécies como fonte de calorias (WEIMER, 2014, p. 168). Considerando a região da Saracura como um lugar de persistência, podemos dizer que ela possui características únicas e adequadas às práticas comportamentais humanas ${ }^{8}$, favorecendo a defesa e o fornecimento de recursos, como água e alimento.

Através da análise histórico-cartográfica, observamos na Saracura alguns pontos específicos, lugares associados à vida social do antigo quilombo e sua relação com o ambiente ao redor. O Tanque do Reúno, ponto de referência na paisagem da Saracura do século XIX, desaparece na cartografia entre 1897 e 1905. Segundo Affonso A. Freitas em Tradições e Reminiscências Paulistanas (1978, p.28), essa represa abasteceu por quase dez anos duas fontes da cidade, a do Largo do Piques e a da Luz entre os anos de 1868 e 1876. Na historiografia da cidade, está registrado que em 1845 o governador da província recomendava ao poder público municipal a proibição da lavagem de roupas no Tanque do Reúno, para que não sujassem a água que era potável e de proveito

\footnotetext{
${ }^{8}$ (SCHLANGER, 1992)
} 
Artigo | Vestígios de um quilombo paulistano: uma análise da paisagem arqueológica do bairro do Bixiga (LIMA, Alessandro Luís Lopes de)

público (BRUNO, 1954, p.654). Acreditamos que o trabalho de lavagem de roupas por parte das mulheres negras era um dos usos que a comunidade da Saracura fazia do tanque, essa era uma provável forma de garantir o sustento econômico desse antigo quilombo urbano.

Outro ponto de interações relacionado ao antigo quilombo e que aparece bastante na cartografia histórica são as Matas do Caanguçu. Elas serviam como fonte de recursos e alimentação; perdizes e veados poderiam ser caçados na região, e até 1880 esses cervídeos ainda eram vistos nessas matas (FREITAS, 1978, p.21; p.181). Toda natureza no entorno permitia aos quilombolas viverem da coleta, da pesca de peixes e de caranguejos. A mata era fonte da extração do palmito e fornecia a matéria-prima para outras comidas vendidas pelas mulheres negras do comércio ambulantes. Elas ofereciam em seus tabuleiros carás cozidos, pinhões, cuscuz de bagre, jabuticabas, araçás, guabirobas, pitangas, cambucis, entre outros frutos vindos das matas do Caanguçu (BRUNO, 1954; ROLNIK, 1997, p.61-62).

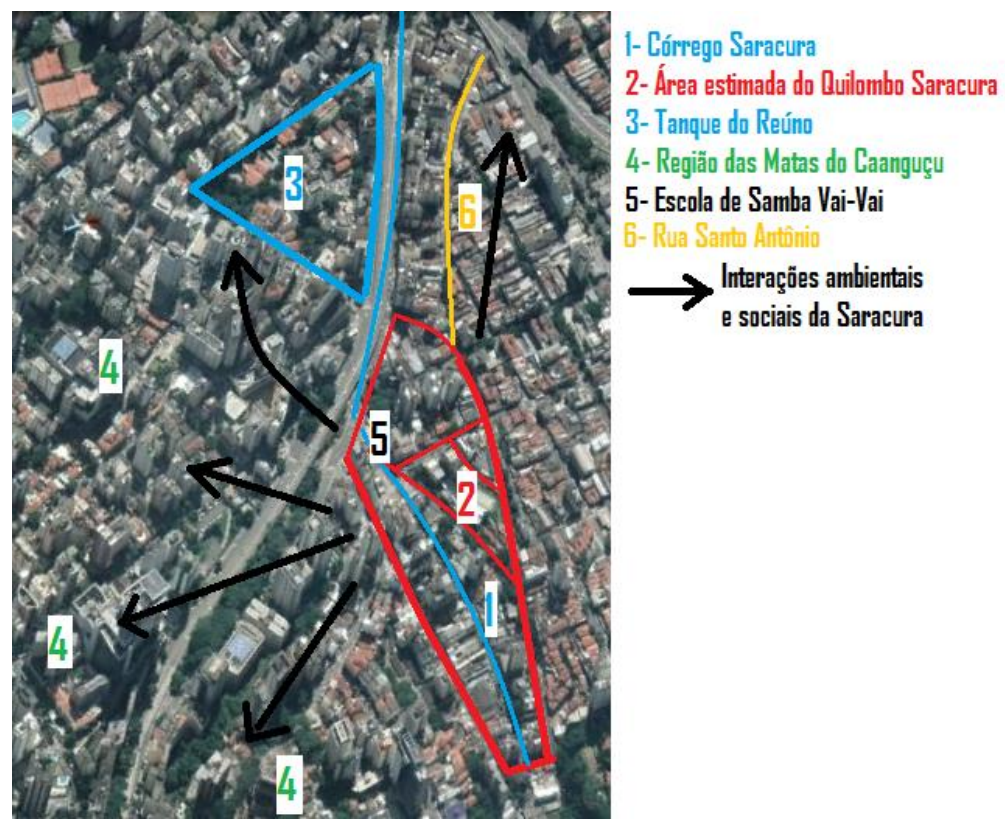

Figura 26. (Fonte: Google Earth, 2019).

Com a chegada da urbanização na passagem do século XIX para o XX, diminui significativamente a vegetação do Caanguçu e o Tanque do Reúno desaparece na paisagem. Nesse momento surgem novas formas de relações econômicas entre a 
Artigo | Vestígios de um quilombo paulistano: uma análise da paisagem arqueológica do bairro do Bixiga (LIMA, Alessandro Luís Lopes de)

população da Saracura e os casarões da Avenida Paulista, que necessitavam de serviços domésticos (ROLNIK, 1997, p. 76).

O levantamento do registro arqueológico da Saracura através da análise da cartografia-histórica, nos permite enxergar as interações e atividades que mantiveram e transformaram esse território e sua paisagem. Através desse pressuposto, identificamos possíveis estratégias de uso da terra e as mudanças na paisagem natural. Visualizamos algumas das atividades comportamentais desse antigo quilombo. Segundo a arqueóloga Zedeño (1997), os elementos materiais do território são a terra, os recursos naturais e os objetos produzidos pelo homem. Nesse entendimento, o território possui três dimensões que devem ser buscadas: 1) as interações homem-terra; 2) a escala espacial dessas relações; 3) a história do uso dos recursos e da própria terra. Sendo os territórios unidades empíricas, verificáveis, sua história de vida pode ser sistematicamente reconstruída.

Os caminhos e vias relacionadas à história da Saracura integravam a comunidade internamente e com o exterior. A Rua Dr. Lourenço Granato, por ser paralela ao curso da Saracura grande, provavelmente representa um lugar relacionado à ocupação original do quilombo. Apesar de não aparecer na cartografia histórica oficial durante o século XIX e início do XX, é possível que sua existência enquanto passagem seja bem mais antiga do que indica a documentação cartográfica. A Dr. Lourenço Granato começa a aparecer na cartografia oficial apenas no mapa de 1916 (figura 19), como uma leve curva ao final da Rua Conselheiro Carrão. Na carta de 1930 ela aparece (figura 20), mas ainda não inteira, como se encontra hoje em dia. Na Rua Dr. Lourenço Granato, havia lotes estreitos e compridos, como vemos no mapa de 1930, tendo como fundo o próprio córrego da Saracura grande. Nesse lugar é onde provavelmente se encontrava o assentamento do quilombo. Intervenções arqueológicas sistematizadas no subsolo da região da Saracura poderiam vir a confirmar, ou não, essas nossas afirmações. 


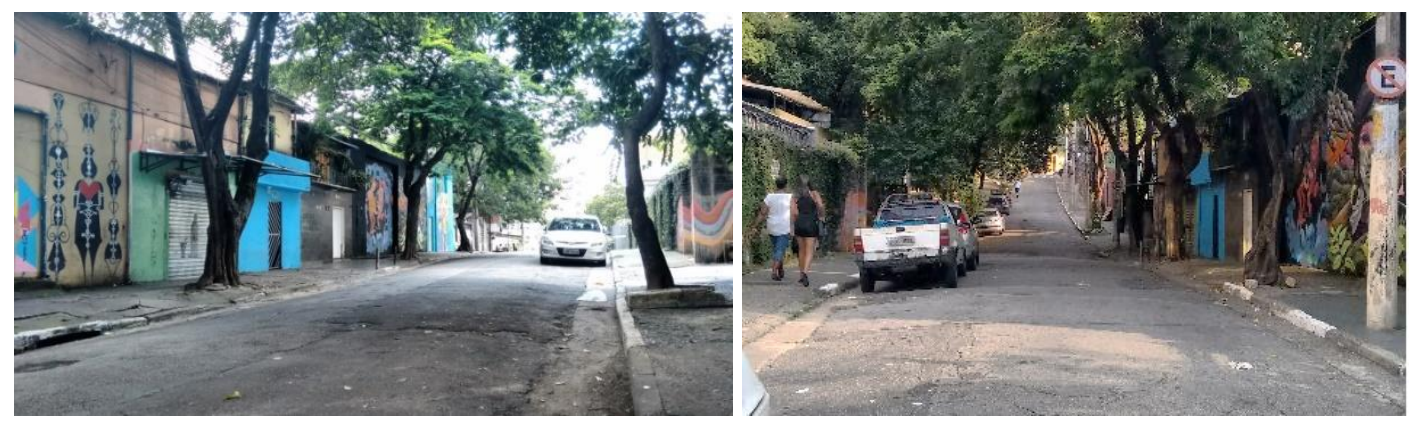

Figuras 27 e 28. Rua Dr. Lourenço Granato. Locus espacial da população do Quilombo da Saracura. (Fonte: Alessandro Lima, mar./2018).

Outra referência importante é a própria Rua Cardeal Leme, por onde hoje passa canalizado o córrego da Saracura grande. Essa rua possui grande valor para a memória local já que corre em seu subsolo, um dos elementos naturais que determinaram o surgimento da ocupação e que deu nome à comunidade por quase de 200 anos.

As Ruas Almirante Marques Leão e Santo Antônio, eram as vias mais antigas de acesso e contato entre os quilombolas e o triângulo histórico. A Rua Tenáglia, provavelmente é um vestígio de uma antiga curva da Rua Almirante Marques Leão. Essa curva, que aparece na documentação desde a carta de 1842, deveria seguir os níveis do acidentado relevo da região, desviando de alguma elevação natural. A Rua Almirante Marques Leão, identificada na cartografia como "Caminho da Saracura grande", após o ponto de encontro com a Rua Dr. Lourenço Granato (figuras 22 e 23), provavelmente constituía parte importante do locus espacial da antiga comunidade. Na documentação cartográfica, podemos ver nesse trecho da Rua Almirante Marques Leão, contínuos lotes irregulares, estreitos e compridos que davam para o córrego Saracura (figura 20).

\section{Conclusão}

A diáspora africana nas Américas e no Brasil teve um caráter de mão dupla, que transformou, mas também manteve aspectos da cultura africana (FERREIRA, 2009). Uma boa parte dos territórios brasileiros carrega a influência do modelo africano de urbanização. Essas formas deram origem a diversas vilas e bairros no Brasil. Os quilombos urbanos cresceram tanto que atingiram até a metade de cidades contemporâneas, em bairros com maioria negra e onde as formas tradicionais africanas impuseram sua urbanização e seu arruamento. Independente da morfologia do 
Artigo | Vestígios de um quilombo paulistano: uma análise da paisagem arqueológica do bairro do Bixiga (LIMA, Alessandro Luís Lopes de)

ambiente, essa padrão de ocupação espacial permanece, tanto em morros quanto em planícies (WEIMER, 2008; 2014).

Reconhecemos na região da baixada do antigo Quilombo da Saracura significativo valor arqueológico, já que permanecem na paisagem os vestígios da sua antiga materialidade e de suas interações ambientais e sociais. Essas ruas e vias, restos da infraestrutura comunitária ou do antigo curso d’água, são partes originárias da ocupação do território. Conforme os elementos aqui levantados, definimos a região como uma paisagem cultural e biopolítica, nos termos comentados por Rossano Lopes Bastos e Marise Campos de Souza (2010). A urbanização da região revela uma paisagem organicamente em evolução, definida pelo humano, mas que atinge sua completude apenas em associação ao ambiente natural. A região da Saracura hoje é uma paisagem fóssil, onde as suas características materiais permaneceram. Também é uma paisagem associativa e contínua, viva, quando além de local de moradia se torna referência para a identidade afro-paulistana e reduto permanente de grandes festas da Escola de Samba Vai-Vai. A Saracura não se define através de conceitos cindidos e segmentados, ela é simultaneamente natureza e cultura, e dessa forma se constituiu como paisagem urbana e patrimônio afro-brasileiro do município de São Paulo.

\section{Referências}

ALEXANDRE, C. R. Religiões afro-brasileiras e organizações carnavalescas de São Paulo: Santos e Orixás na Vai-Vai e a Tradição no Bairro da Bela Vista. Anuário Unesco/ Metodista de Comunicação Regional, Ano 19, n¹9, p.195-213, 2015.

ALEXANDRE, C. R. Exu e Ogum no terreiro de samba- um estudo sobre a religiosidade da Escola de Samba Vai-Vai. Dissertação de Mestrado- PUC-SP, 2017.

ASHMORE, W.; KNAPP, A. B. Archaeologies of Landscapes: Contemporary Perspectives. Black Well Publishers, Oxford, 1999.

BASTOS, R., SOUZA, M. C. (org.) Normas e Gerenciamento do Patrimônio Arqueológico. IPHAN-SP, 2010.

BRUNO, E. S. Histórias e Tradições da cidade de São Paulo. Arraial dos sertanistas (15541828), v.1. Comissão do IV centenário da Cidade de São Paulo, São Paulo; 1954.

BRUNO, E. S. Histórias e Tradições da cidade de São Paulo. Burgo de estudantes (18281872), v.2. Comissão do IV centenário da Cidade de São Paulo, São Paulo; 1954.

BRUNO, E. S. Histórias e Tradições da cidade de São Paulo. Metrópole do Café (18721918); São Paulo de Agora (1919-1954), v.3. Comissão do IV centenário da Cidade de São Paulo, São Paulo; 1954. 
Artigo | Vestígios de um quilombo paulistano: uma análise da paisagem arqueológica do bairro do Bixiga (LIMA, Alessandro Luís Lopes de)

CASTRO, M. S. Bexiga. Um bairro afro-italiano: comunicação, cultura e construção da identidade étnica. Dissertação de Mestrado - ECA/USP, 2008.

DIAS, M. O. L. S. Quotidiano e poder em São Paulo no século XIX. São Paulo: Brasiliense, 1984.

FERREIRA, L. M. Sobre o conceito de Arqueologia da Diáspora Africana. MÈTIS: História \& Cultura, v.8, n.16, 2009: p.267-275.

FREITAS, A. A. Tradições e Reminiscências Paulistanas. São Paulo: volume IX, Coleção Paulística, 1978.

FLORENTINO, M.; AMANTINO, M. Uma morfologia dos quilombos nas Américas, séculos XVI-XIX. História, Ciências, Saúde - Manguinhos, Rio de Janeiro, v.19, supl., dez. 2012, p.259297.

FUNARI, P. P. A., POLONI, R. J. S. Arqueologia urbana: trajetória e perspectivas. Revista do Arquivo Municipal, São Paulo, v. 205, ano 80, 2014: p. 137-154.

HODDER, I.; HUTSON, S. Reading the Past: Current approaches to interpretation in archaeology. Cambridge University Press, New York, 2003.

LÉVI-STRAUSS, C. Saudades de São Paulo. Cia das Letras, São Paulo, 1996.

LUCENA, C. T. Bairro do Bexiga. A sobrevivência cultural. São Paulo: brasiliense, 1984.

MENESES, U. T. B.; A cidade como bem cultural: áreas envoltórias e outros dilemas, equívocos e alcance da preservação do patrimônio ambiental urbano (p.33-76). In: MORI, V. H.; SOUZA, M. C.; BASTOS, R. L.; GALLO, H (org.). Patrimônio: atualizando o debate. São Paulo: $9^{\circ}$ SR/IPHAN, 2006.

MOURA, C. Revoltas em São Paulo (p.221-242). In: Rebeliões da Senzala: quilombos, insurreições e guerrilhas. Porto Alegre: Mercado aberto, 1988.

ORSER, JR. C. E. A Historical Archaeology of the Modern World: contributions to Global Historical Archaeology. New York and London: Plenum Press, 1996.

ORSER, JR., C. E. A Teoria de Rede na Arqueologia Histórica Moderna, Revista do Museu de Arqueologia e Etnologia/USP. São Paulo, n.3, 1999: p. 87-101.

PRADO JR., C. A Cidade de São Paulo. Geografia e história. São Paulo: Brasiliense, 1983.

ROLNIK, R. Territórios negros nas cidades brasileiras: etnicidade e cidade em São Paulo e no Rio de Janeiro. Estudos Afro-Asiáticos, Rio de Janeiro, n. 17, 1989: p. 29-41.

ROLNIK, R. A cidade e a lei: legislação, política urbana e territórios na cidade de São Paulo. São Paulo: Studio Nobel, 2003.

SCHLANGER, S. H. Recognizing persistent places in Anasazi settlement systems. pp. 91112. In, Rossignoi, J., and Wanclsnider, L. (eds.), Space, time and Archaeological Landscapes. Plenum Press, New York, 1992.

SCHIFFER, M. B. Archaeological context and systemic context. American Antiquity, v. 37, n.2, 1972: p.156-165.

SODRÉ, M. O terreiro e a cidade: a forma social negro-brasileira. Rio de Janeiro: Imago Ed., 2002.

TEIXEIRA, M. A Arqueologia da cidade através da cartografia urbana histórica. In: Atas do $\mathrm{VI}^{\circ}$ Simpósio Luso-Brasileiro de Cartografia Histórica. Universidade Técnica de Lisboa. Braga, 2019.

TOLEDO, B. L. São Paulo: três cidades em um século. São Paulo: Liv. Duas Cidades, 1983. 
Artigo | Vestígios de um quilombo paulistano: uma análise da paisagem arqueológica do bairro do Bixiga (LIMA, Alessandro Luís Lopes de)

WEIMER, G. Inter-relações Arquitetônicas Brasil-África. Pronunciamento de posse como membro efetivo do Instituto Histórico e Geográfico do Rio Grande do Sul, 28 de maio de 2008. Instituto Histórico Geográfico do Rio Grande do Sul, 2008.

WEIMER, G. Inter-relações afro-brasileiras na Arquitetura. EDIPUCRS. Porto Alegre, 2014.

WISSENBACH, M. C. C. Sonhos africanos, vivências ladinas. Escravos e forros em São Paulo (1850-1880). São Paulo: Hucitec, 1998.

ZEDEÑO, M. N. Landscapes, Land Use, and the History of Territory Formation: An Example from the Puebloan Southwest; Journal of Archaeological Method and Theory, Vol. 4, No. 1, 1997.

\section{Fontes da Cartografia Histórica}

Figura 9. SISTEMA DE CONSULTA DO MAPA DIGITAL DA CIDADE DE SÃO PAULO. Planta da cidade de São Paulo. [1810]. 1 mapa, color. Escala 1/3?. Disponível em: $<$ http://geosampa.prefeitura.sp.gov.br/PaginasPublicas/ SBC.aspx\#>. Acesso em $18 \mathrm{de}$ fev. 2018.

Figura 10. SISTEMA DE CONSULTA DO MAPA DIGITAL DA CIDADE DE SÃO PAULO. Carta da capital de São Paulo. [1842]. 1 mapa, color. 1/200 braças. Disponível em: $<$ http://geosampa.prefeitura.sp.gov.br/PaginasPublicas/ SBC.aspx\#>._Acesso em $18 \mathrm{de}$ fev. 2018.

Figura 11. SISTEMA DE CONSULTA DO MAPA DIGITAL DA CIDADE DE SÃO PAULO. Mappa da imperial cidade de S. Paulo. [1855]. 1 mapa, color. Escala 1:10.000 Disponível em: $<$ http://geosampa.prefeitura.sp.gov.br/PaginasPublicas/ SBC.aspx\#>._Acesso em 18 de fev. 2018.

Figura 12. SISTEMA DE CONSULTA DO MAPA DIGITAL DA CIDADE DE SÃO PAULO. Planta da cidade de São Paulo levantada pela Companhia Gantareira e Esgotos. [1881] 1 mapa, preto. Escala 1:10.000. Disponível em: $<$ http://geosampa.prefeitura.sp.gov.br/PaginasPublicas/ SBC.aspx\#>_Acesso em 18 de fev. 2018.

Figura 13. SISTEMA DE CONSULTA DO MAPA DIGITAL DA CIDADE DE SÃO PAULO. Planta da capital do Estado de S. Paulo e seus arrabaldes. [1890]. 1 mapa, color.. Escala 1:10.000. Disponível em: <http://geosampa.prefeitura.sp.gov.br/PaginasPublicas/ SBC.aspx\#>_Acesso em 18 de fev. 2018.

Figura 14. ARQUIVO NACIONAL DO BRASIL. Planta da cidade de São Paulo com indicação dos primeiros edifícios públicos. [1893].1 mapa, color. Escala 1:10.000. Disponívelem:<https://www.flickr.com/photos/arquivonacionalbrasil/27477579247/in/datepo sted $>$ Acesso em 04 de dez. 2019.

Figura 15. SISTEMA DE CONSULTA DO MAPA DIGITAL DA CIDADE DE SÃO PAULO. Planta geral da capital de São Paulo. [1897]. 1 mapa, color. Escala 1:20.000. Disponível em: $<$ http://geosampa.prefeitura.sp.gov.br/PaginasPublicas/ SBC.aspX\#>_Acesso em 18 de fev. 2018.

Figura 16. SISTEMA DE CONSULTA DO MAPA DIGITAL DA CIDADE DE SÃO PAULO. Planta geral da cidade de S. Paulo adoptada pela Prefeitura Municipal para uso de suas repartições. [1905] 1 mapa, color. Escala 1:20.000. Disponível em: http://geosampa.prefeitura.sp.gov.br/PaginasPublicas/ SBC.aspx\# Acesso em 18 de fev. 2018. 
Artigo | Vestígios de um quilombo paulistano: uma análise da paisagem arqueológica do bairro do Bixiga (LIMA, Alessandro Luís Lopes de)

Figura 17. SISTEMA DE CONSULTA DO MAPA DIGITAL DA CIDADE DE SÃO PAULO. Planta da cidade de São Paulo. [1913] 1 mapa, color. Escala 1:15.000. Disponível em: http://geosampa.prefeitura.sp.gov.br/PaginasPublicas/ SBC.aspx\#Acesso em 18 de fev. 2018.

Figura 19. SISTEMA DE CONSULTA DO MAPA DIGITAL DA CIDADE DE SÃO PAULO. Planta da cidade de São Paulo levantada pela divisão cadastral da $2^{\circ}$ Secção da Directoria de Obras e Viação da Prefeitura Municipal. [1916]. 1 mapa, color. Escala 1:20.000. Disponível em: $<$ http://geosampa.prefeitura.sp.gov.br/PaginasPublicas/ SBC.aspx\#>_Acesso em 18 de fev. 2018.

Figura 20. SISTEMA DE CONSULTA DO MAPA DIGITAL DA CIDADE DE SÃO PAULO. Mappa Topográfico do Município de São Paulo. [1930]. 1 mapa, color. Escala 1:50.000. Disponível em: http://geosampa.prefeitura.sp.gov.br/PaginasPublicas/ SBC.aspx\# Acesso em 18 de fev. 2018. 